\title{
PENGARUH TINGKAT PEMAHAMAN PAJAK DAN SANKSI PAJAK TERHADAP KEPATUHAN WAJIB PAJAK DI KABUPATEN TAKALAR
}

\author{
Atia Kirana $\mathrm{W}^{1}$, Usri Usran ${ }^{2}$ \\ STIE AMKOP Kampus : Jl. Meranti No. 1. Panakkukang, Kota Makassar \\ Telp. 0411-440679 Fax.0411-456965 \\ Jurusan Akuntansi STIE AMKOP Makassar \\ Email : kiranaku28@gmail.com ${ }^{1}$, usriusran24@gmail.com²
}

\begin{abstract}
Abstrak
Tujuan dari pelaksanaan penelitian ini adalah untuk mengkaji karakteristik pemahaman pajak dan saknsi pajak terhadap kepatuhan wajib pajak. Populasi penelitian ini adalah wajib pajak yang terdaftar di kantor pajak kabupaten takalar dengan jumlah sampel yang dapat dijadikan responden sebanyak 100 orang. Metode analisis yang digunakan adalah Statistik Deskriptif dan Analisis Regresi Linear Berganda. Penelitian ini menggunakan metode pengumpulan data berupa metode angket (kuisioner), data dianalisis menggunakan program sstatistik SPSS

Hasil penelitian ini menjelaskan bahwa tidak terdapat pengaruh yang signifikan antara variabel pemahaman pajak terhadap kepatuhan wajib pajak sedangkan variabel sanksi pajak terdapat pengaruh yang psitif dan signiikan terhadap kapatuhan wajin pajak. Hasil Pengujian koefisien determinasi diperoleh nilai adjusted $R$ square adalah 0,466. Hal ini menunjukkan bahwa sebesar 46,6\% kepatuhan wajib pajak dipengaruhi oleh variasi kedua variabel, yaitu pemahaman pajak (X1), dan sanksi pajak (X2). Sedangkan sisanya sebesar 53,4\% dipengaruhi oleh variabel-variabel lainnya yang tidak diteliti. Hasil analisis data mendukung hipotesis penelitian yang menyatakan bahwa pemahaman pajak memiliki pengaruh positif terhadap kepatuhan wajib pajak pada kantor pajak di kabupaten Takalar. Hasil analisis data mendukung hipotesis penelitian yang menyatakan bahwa sanksi pajak memiliki pengaruh positif terhadap kepatuhan wajib pajak. Sedangkan Hasil analisis uji coefficient standardized beta diketahui diketahui nilai koefisien beta terstandarisasi (B) variabel Sanksi Pajak (B1) sebesar 0.682 lebih besar dari koefisien beta terstandarisasi variabel Pemahaman Pajak (B2) sebesar 0.034. dengan demikian dapat dikatakan bahwa variabel Sanksi Pajak mempunyai pengaruh dominan terhadap Kepatuhan wajib pajak. Sehingga pengujian hipotesis Sanksi Pajak mempunyai pengaruh yang dominan terhadap kepatuhan wajib pajak pada kantor Pajak di Kabupaten Takalar.
\end{abstract}

Kata kunci : Pemahaman Pajak, Sanksi Pajak, Kepatuhan Wajib Pajak di Kabupaten Takalar

\begin{abstract}
The purpose of this research is to examine the characteristics of tax understanding and tax significance on taxpayer compliance. The population of this research is taxpayers who are registered at the takalar district tax office with a total sample of 100 people who can be respondents. The analytical method used is descriptive statistics and multiple linear regression analysis. This study used a data collection method in the form of a questionnaire method. The data were analyzed using the SPSS statistical program

The results of this study explain that there is no significant influence between the tax understanding variable on taxpayer compliance while the tax sanction variable has a positive and significant effect on tax pay compliance. The test results obtained by the coefficient of determination the adjusted $R$ square value is 0.466. This shows that $46.6 \%$ of taxpayer compliance is influenced by the variation of the two variables, namely tax understanding (XI) and tax sanctions (X2). While the remaining $53.4 \%$ is influenced by other variables which are
\end{abstract}




\section{AkMen

not researched. The results of data analysis support the research hypothesis which states that tax understanding has a positive effect on taxpayer compliance at the tax office in Takalar district. The results of data analysis support the research hypothesis which states that tax sanctions have a positive effect on taxpayer compliance. While the results of the analysis of the standardized beta coefficient test, it is known that the value of the standardized beta coefficient $(\beta)$ of the Tax Sanctions variable $(\beta 1)$ is 0.682 greater than the standardized beta coefficient of the Tax Understanding variable ( $\beta 2)$ of 0.034. Thus it can be said that the Tax Sanctions variable has a dominant influence on taxpayer compliance. So that the Tax Sanctions hypothesis testing has a dominant influence on taxpayer compliance at the Tax Office in Takalar Regency.

Keywords: Tax Understanding, Tax Sanctions, Taxpayer Compliance in Takalar Regency

\section{PENDAHULUAN}

Peningkatan penerimaan negara dari sektor pajak sebagai salah satu sumber pembiayaan yang masih dimungkinkan dan terbuka luas, di dasarkan pada jumlah pembayaran pajak dari tahun ke tahun yang diharapkan semakin banyak seiring dengan semakin bertambahnya jumlah penduduk dan kesejahteraaan masyarakat. Dimana Pajak merupakan sumber penerimaan utama negara yang digunakan untuk membiayai pengeluaran pemerintah dan pembangunan. Hal ini tertuang dalam Anggaran Penerimaan dan Belanja Negara (APBN) dimana penerimaan pajak merupakan penerimaan dalam negeri yang terbesar. Semakin besarnya pengeluaran pemerintah dalam rangka pembiayaan negara menuntut peningkatan penerimaan negara yang salah satunya berasal dari penerimaan pajak. Direktorat Jenderal (Ditjen) Pajak sebagai instansi pemerintahan di bawah Departemen Keuangan sebagi pengelola sistem perpajakan di Indonesia berusaha meningkatkan penerimaan pajak dengan mereformasi pelaksanaan sistem perpajakan yang lebih modern. Menurut Mardiasmo, (2011) Pajak merupakan iuran wajib yang dibayar rakyat kepada negara tanpa kontraprestasi secara langsung dan akan digunakan untuk kepentingan pemerintah dan masyarakat umum. Sedangkan menurut Siti Resmi (2013) pajak mempunyai dua fungsi penting dalam perekonomian suatu negara. Pertama pajak merupakan salah satu sumber dana pemerintah untuk melakukan pembangunan, baik pemerintah pusat maupun pemerintah daerah. Kedua pajak berfungsi sebagai alat yang mengatur kebijakan-kebijakan pemerintah di bidang sosial ekonomi.

Menyadari akan besarnya peranan pajak untuk menggerakkan roda pemerintah dan pembangunan maka sejak tahun 1983 telah dilakukan usaha-usaha dalam bentuk reformasi sistem perpajakan nasional secara terus menerus. Terakhir dikeluarkan Undang-undang RI No. 42 tahun 2009, yang merupakan perubahan ketiga dari UndangUndang RI No. 8 tahun 1983 tentang Pajak Pertambahan Nilai. Reformasi sistem perpajakan nasional memang dapat dikatakan telah meningkatkan penerimaan pajak. Namun kecepatan pertumbuhan penerimaan pajak belum mencapai hasil yang seperti diharapkan. Hal tersebut dibuktikan dengan rendahnya tax ratio Indonesia. Faktor yang menyebabkan rendahnya tax ratio adalah rendahnya pendapatan per kapita, tingkat kepatuhan wajib pajak yang masih rendah (kesadaran masyarakat akan kewajiban perpajakan masih sangat rendah), wajib pajak dalam melaporkan peredaran usaha dan penghasilannya sebagian besar belum dilakukan secara transparan, dan tingkat efisiensi administrasi perpajakan yang belum maksimal. Rendahnya kesadaran masyarakat akan kewajiban perpajakan ini seringkali disebabkan oleh karena ketidaktahuan masyarakat 


\section{AkMen

akan aturan perpajakan. (Yadnyana dan Sudiksa, 2011). Kepatuhan wajib pajak dipengaruhi oleh beberapa faktor dalam peningkatannya. Diantaranya adalah pemahaman dari wajib pajak terhadap peraturan perpajakan. Peningkatan kepatuhan wajib pajak tidak terlepas dari pemahaman wajib pajak terhadap Undang-Undang dan peraturan perpajakan dan faktor individu yaitu sikap dari masyarakat wajib pajak. Kedua faktor ini akan mempengaruhi kepatuhan masyarakat untuk memenuhi kewajibannya dibidang perpajakan. Kepatuhan dalam wajib pajak akan mendorong terhadap peningkatan penerimaan negara dari sektor pajak.

Sejak tahun 2014 hingga tahun 2018 penerimaan pajak di Indonesia kian meningkat. Walau penerimaan mengalami kenaikan, penerimaan pajak masih belum mencapai target yang telah ditentukan. Untuk mencapai target yang telah ditentukan, Indonesia melakukan tindakan lebih agar sampai pada target penerimaan pajak yang telah ditentukan. Dengan meningkatnya sumber pendapatan pada pajak maka dapat digunakan untuk membiayai pengeluaran pemerintah dan pembangunan lainnya misalnya, pada tahun 2018 di sektor pendidikan pemerintah memberikan jatah $20 \%$ dari total APBN dan jumlah tersebut telah di cover oleh keberadaan pajak. Hal ini juga tertuang dalam UUD 1945 dalam pasal 31 ayat (4) dan juga dalam UU Sisdiknas, dalam Pasal 49 ayat (1)-nya mengamanatkan bahwa dana pendidikan selain gaji pendidik dan biaya pendidikan kedinasan dialokasikan minimal 20\% dari Anggaran Pendapatan dan Belanja Negara (APBN)..Tidak hanya pendidikan, pajak sebagai sumber pendapatan, juga mampu meng-cover kebutuhan sektor kesehatan dari total APBN yang mencapai 5\% (Retno Kadarukmi, 2012) . Melihat dari kedua hal di atas, dapat di simpulkan bahwa peran pajak sebagai sumber pendapatan Negara sangatlah penting, sehingga keberadaannya sangat dibutuhkan. Kurangnya jumlah pajak yang didapat tak lepas dari minimnya tingkat kesadaran masyarakat dan badan usaha tentang pentingnya membayar pajak. Minimnya angka kesadaran masyarakat dan badan usaha akan pajak memang mengkhawatirkan. Oleh karenanya, untuk meningkatkan kesadaran masyarakat untuk membayar pajak, pemerintah yang dalam hal ini adalah pihak yang menerima pajak, wajib melakukan aneka tindakan dan cara untuk mengangkat angka kesadaran masyarakat akan pajak. Takalar,

Berikut adalah daftar wajib pajak orang pribadi yang terdaftar di KPP kabupaten

Tabel 1.1

Wajib Pajak Orang Pribadi yang Terdaftar di KPP Kabupaten Takalar

\begin{tabular}{|c|c|c|c|c|c|}
\hline Keterangan & 2014 & 2015 & 2016 & 2017 & 2018 \\
\hline WP OP Terdaftar & 5.136 & 4.684 & 5.231 & 6.109 & 6.757 \\
\hline
\end{tabular}

Sumber : KPP Kabupaten Takalar 2020

Berdasarkan daftar tabel di atas dapat di uraikan bahwa Wajib Pajak Orang Pribadi yang terdaftar dari tahun ke tahun selalu mengalami peningkatan pada tahun 2014 sebanyak 5.136, tahun 2015 sebanyak 4.684, tahun 2016 sebanyak 5.231, tahun 2017 sebanyak 6.109 dan pada tahun 2018 sebanyak 6.757 wajib pajak artinya setiap tahun mengalami kenaikan jumlah Wajib Pajak Orang Pribadi yang terdaftar di KPP Kabupaten Takalar. 
Tabel 1.2

Daftar Wajib Pajak Orang Pribadi di KPP Kabupaten Takalar

\begin{tabular}{|c|c|c|c|c|c|}
\hline Keterangan & 2014 & 2015 & 2016 & 2017 & 2018 \\
\hline $\begin{array}{c}\text { Realisasi SPT } \\
\text { WP OP Terdaftar }\end{array}$ & 3.683 & 3.412 & 3.894 & 4.156 & 5.236 \\
\hline
\end{tabular}

Sumber : KPP Kabupaten Takalar

Berdasarkan tabel di atas realisasi yang menyampaikan SPT Tahunan Wajib Pajak Orang Pribadi pada tahun 2014 sebanyak 3.683, tahun 2015 sebanyak 3.412, tahun 2016 sebanyak 3.894, tahun 2017 sebanyak 4.156 dan pada tahun 2018 sebanyak 5.236, artinya setiap tahun jumlah Wajib Pajak Orang Pribadi yang menyampaikan SPT tahunan setiap tahun mengalami kenaikan walaupun jumlah perbedaan tidak besar.

Pemahaman wajib pajak terhadap peraturan perpajakan adalah cara wajib pajak dalam memahami peraturan perpajakan yang telah ada (Hardiningsih, 2011). Fenomena yang terjadi saat ini adalah masih banyaknya wajib pajak yang belum memahami akan peraturan pajak. Seorang wajib pajak dapat dikatakan patuh dalam kegiatan perpajakan perlu memahami secara penuh tentang peraturan perpajakan antara lain mengetahui dan berusaha memahami Undang-Undang Perpajakan, cara pengisian formulir perpajakan, cara menghitung pajak, Selalu membayar pajak tepat waktu, cara melaporkan SPT. Pada fenomena yang terjadi tersebut memiliki pengaruh yang besar terhadap seseorang dalam memenuhi kewajibannya dalam perpajakan. Dalam hal pengetahuan wajib pajak terhadap peraturan perpajakan dapat dikatakan belum semua wajib pajak memahami. Masih ada wajib pajak yang menunggu ditagih baru membayar pajak, seperti peraturan pajak pada periode lama. Hal ini dapat menurunkan jumlah penerimaan pajak negara serta tingkat kepatuhan wajib pajak. Sejak terbitnya Undang-undang Nomor 6 Tahun 1983, yang kemudian diubah dengan UU No. 28 Tahun 2007 tentang Ketentuan Umum dan Tata Cara Perpajakan (KUP) dikenal istilah Self Assessment System yang memberikan kepercayaan kepada wajib pajak untuk menghitung, membayar, dan melaporkan sendiri pajak terutangnya. Dengan dianutnya sistem Self Assessment System, maka selain bergantung pada kesadaran dan kejujuran wajib pajak, pengetahuan teknis perpajakan yang memadai juga memegang peran penting, agar wajib pajak dapat melaksanakan kewajiban perpajakannya dengan baik dan benar. Karena melalui sistem ini, setiap wajib pajak di wajibkan mengisi sendiri dan menyampaikan Surat Pemberitahuan (SPT) Tahunan dengan benar, lengkap, dan jelas (Wulandari, 2007 dalam Nugroho, 2012). Menurut (Lovihan 2014) Pemahaman peraturan perpajakan adalah cara wajib pajak dalam memahami peraturan perpajakan yang telah ada. Wajib pajak yang tidak memahami peraturan perpajakan secara jelas cenderung akan menjadi wajib pajak yang tidak taat. Jelas bahwa semakin paham wajib pajak terhadap peraturan perpajakan, maka semakin paham pula wajib pajak terhadap sanksi yang akan diterima bila melalaikan kewajiban perpajakan mereka. Dimana wajib pajak yang benar-benar paham, mereka akan tahu sanksi adminstrasi dan sanksi pidana sehubungan dengan SPT dan NPWP. Pemahaman wajib pajak mengenai aturan dan ketentuan perpajakan yang berlaku di Indonesia diharapkan akan meningkatkan kepatuhan pajak. Kepatuhan wajib pajak dapat diukur dari pemahaman terhadap semua 


\section{AkMen \\ Volume 18 Nomor 1 April 2021 \\ Hal. 110 - 122 \\ e-ISSN : 2621-4377 \& p-ISSN : 1829-8524 \\ Homepage: https//e-jurnal.stienobel-indonesiaacid/indexphp/akmen}

ketentuan peraturan perundang-undangan perpajakan, mengisi formulir dengan lengkap dan jelas, menghitung jumlah pajak yang terutang dengan benar, membayar dan melaporkan pajak yang terutang tepat pada waktunya. Sebelumnya penelitian menunjukkan bahwa pengetahuan pajak penting dalam rangka meningkatkan tingkat kepatuhan pajak (Richardson, 2006) dalam Hardiningsih (2011). Artinya, wajib pajak lebih bersedia untuk mematuhi aturan dan ketentuan yang berlaku jika mereka memahami konsep dasar perpajakan.

Menurut Mardiasmo (2016:39) "Sanksi perpajakan merupakan jaminan bahwa ketentuan peraturan perundang-undangan perpajakan (norma perpajakan) dituruti/ditaati/dipatuhi, bisa dikatakan sanksi perpajakan alat pencegah agar wajib pajak tidak melanggar norma perpajakan agar Undang-Undang dan peraturan dipatuhi, maka harus ada sanksi bagi pelanggarannya". Berbagai cara telah dilakukan oleh pemerintah agar dapat meningkatkan kepatuhan Wajib Pajak yang masih rendah, seperti dilaksanakannya berbagai sosialisasi dan memberikan Sanksi Perpajakan. Dilihat dari peristiwa dimana terdapat $25 \%$ wajib pajak yang belum menunaikan kewajibannya maka dapat disimpulkan bahwa Kepatuhan Wajib Pajak di Kabupaten Takalar masih rendah. Dengan Sanksi Perpajakan ini diharapkan agar memberikan efek jera pada pelanggar pajak. Dengan demikian wajib pajak akan memenuhi kewajiban perpajakannya bila memandang sanksi pajak lebih banyak merugikannya. Semakin banyak tunggakan yang masih harus dibayar maka semakin berat wajib pajak untuk melunasinya. Subyek dalam penelitian ini adalah Wajib Pajak Orang Pribadi. Wajib Pajak Orang Pribadi yang melakukan kegiatan usaha atau pekerjaan bebas lebih rentan terhadap pelanggaran pajak daripada Wajib Pajak Orang Pribadi yang tidak melakukan kegiatan usaha atau pekerjaan bebas. Hal tersebut dikarenakan mereka melakukan pembukuan atau pencatatan sendiri atas usaha mereka. Pembukuan atau pencatatan yang dilakukan dapat dilaksanakan sendiri maupun mempekerjakan orang yang ahli dalam akuntansi. Namun kebanyakan dari pelaku kegiatan usaha dan pekerjaan bebas tersebut beranggapan bahwa akan kurang efisien apabila mempekerjakan orang untuk melakukan pembukuan atau pencatatan, terutama dalam hal biaya, yang bersangkutan lebih memilih untuk menyelenggarakan pembukuan atau pencatatan sendiri, sehingga menimbulkan kemungkinan kesalahan maupun ketidakjujuran dalam pelaporan pajaknya (Arum, 2012). Kepatuhan suatu spesifikasi, standar, atau hukum yang telah diatur dengan jelas, sedangkan perpajakan adalah perihal pajak. Maka Kepatuhan Wajib Pajak adalah suatu kemauan dan kesadaran Wajib Pajak akan mengenai kewajibannya dalam bidang perpajakan. Kepatuhan Wajib Pajak yang rendah sangat berpengaruh pada penerimaan pajak orang pribadi di Kabupaten Takalar. Penelitian yang dilakukan oleh Widayati dan Nurlis (2010) menemukan bahwa pengetahuan dan pemahaman terhadap peraturan perpajakan mempunyai pengaruh yang signifikan terhadap kemauan wajib pajak untuk membayar pajak.

Penelitian yang di lakukan oleh Josephine Nidya Prajogo dan Retnaningtyas Widuri (2013) tingkat pemahaman peraturan pajak wajib pajak, kualitas pelayanan petugas pajak dan persepsi atas sanksi perpajakan secara bersama-sama berpengaruh signifikan terhadap kepatuhan wajib pajak UMKM di wilayah Sidoarjo

Berdasarkan uraian diatas, maka peneliti tertartik untuk melakukan penelitian mengenai "Pengaruh Tingkat Peamahaman Peraturan Pajak, dan Sanksi Pajak Terhadap Kepatuhan Wajib Pajak di Kabupaten Takalar'. Sesuai dengan latar belakang penelitian yang dikemukakan di atas, maka peneliti merumuskan masalah yang dibahas dalam 
penelitian ini, adalah Apakah tingkat pemahaman pajak dan sanksi pajak berpengaruh positif dan signifikan terhadap kepatuhan wajib pajak pada kantor pajak di kabupaten Takalar?

\section{Pengembangan Hipotesis \\ Pengaruh Tingkat Pemahaman Pajak terhadap Kepatuhan Wajib Pajak pada Kantor Pajak di Kabupaten Takalar.}

Pengetahuan perpajakan adalah kemampuan seorang wajib pajak dalam mengetahui peraturan perpajakan baik itu soal tarif pajak yang akan mereka bayar, maupun manfaat pajak yang akan berguna bagi kehidupan mereka. Dengan adanya pengetahuan perpajakan tersebut akan membantu kepatuhan wajib pajak dalam membayar pajak sehingga tingkat kepatuhan akan meningkat (Banyu Utomo,2011). Penelitian oleh Banyu Utomo, 2011 tentang pengaruh sikap, kesadaran wajib pajak, dan pengetahuan perpajakan terhadap kepatuhan wajib pajak dalam membayar pajak bumi dan bangunan di kecamatan Pamulang Kota Tangerang Selatan menunjukkan secara parsial sikap wajib pajak tidak berpengaruh secara signifikan terhadap kepatuhan wajib pajak, kesadaran wajib pajak berpengaruh secara signifikan terhadap kepatuhan wajib pajak, pengetahuan perpajakan berpengaruh secara signifikan terhadap kepatuhan wajib pajak, dan secara simultan sikap wajib pajak, kesadaran wajib pajak, dan pengetahuan perpajakan berpengaruh secara signifikan terhadap kepatuhan wajib pajak.

H1 : Pengetahuan Perpajakan Berpengaruh Positif Terhadap Kepatuhan Wajib Pajak Bumi dan Bangunan

\section{Pengaruh Sanksi Pajak terhadap Kepatuhan Wajib Pajak pada Kantor Pajak di Kabupaten Takalar.}

Hasil Penelitian Laura Yohana, 2016 tentang Pengaruh Pengetahuan Perpajakan, Kesadaran Wajib Pajak, Sanksi Perpajakan dan Kualitas Pelayanan Pajak terhadap Kepatuhan Wajib Pajak dalam Membayar PBB di Kota Bukittinggi menunjukkan bahwa secara parsial pengetahuan perpajakan berpengaruh tetapi tidak signifikan terhadap kepatuhan wajib pajak, kesadaran wajib pajak berpengaruh signifikan terhadap kepatuhan wajib pajak, sanksi perpajakan berpengaruh signifikan terhadap kepatuhan wajib pajak, kualitas pelayanan pajak berpengaruh tetapi tidak signifikan terhadap kepatuhan wajib pajak, dan secara simultan pengetahuan perpajakan, kesadaran wajib pajak, sanksi perpajakan dan kualitas pelayanan pajak berpengaruh signifikan terhadap kepatuhan wajib pajak.

H2 : Sanksi Perpajakan Berpengaruh Positif Terhadap Kepatuhan Wajib Pajak Bumi dan Bangunan.

\section{METODE PENELITIAN}

Pendekatan yang digunakan dalam penelitian ini adalah pendekatan kuantitatif. Pendekatan kuantitatif digunakan untuk meneliti pada populasi atau sampel tertentu, pengumpulan data menggunakan instrument penelitian, analisis data bersifat kuantitatif/statistik, dengan tujuan untuk menguji hipotesis yang telah ditetapkan. Dalam penelitian ini instrumen penelitian yang digunakan untuk mengetahui pengaruh tingkat pemahaman peaturan pajak dan Sanksi Pajak dengan menggunakan kuesioner yaitu teknik pengumpulan data yang dilakukan dengan menggunakan lembaran 
pertanyaan yang diberikan kepada responden. Penelitian ini ditujukan kepada wajib pajak yang terdaftar di kantor pajak Takalar yang berjumlah 100 orang.

\section{HASIL PENELITIAN DAN PEMBAHASAN Analisis Regresi Berganda}

Koefisien determinasi digunakan untuk mengetahui presentase perubahan variabel tidak bebas (Y) yang disebabkan oleh variabel bebasnya (X).Pada intinya koefisien determinasi mengukur sebarapa jauh kemampuan model dalam menerangkan variasi variabel independen.

Hasil perhitungan adjusted $R$ dapat diketahui berapa persentase yang dapat dijelaskan oleh variabel-variabel bebas terhadap variabel terikat. Sedangkan sisanya dipengaruhi atau dijelaskan oleh variabel-variabel lain yang tidak dimasukkan dalam metode penelitian

Hasil Uji Koefisien Determinasi

Model Summary

\begin{tabular}{|l|l|r|r|r|}
\hline Model & $\mathrm{R}$ & $\begin{array}{c}\mathrm{R} \\
\text { Square }\end{array}$ & $\begin{array}{c}\text { Adjusted R } \\
\text { Square }\end{array}$ & $\begin{array}{c}\text { Std. Error of } \\
\text { the Estimate }\end{array}$ \\
\hline 1 & $.683^{\mathrm{a}}$ & .466 & .455 & 1.831 \\
\hline
\end{tabular}

a. Predictors: (Constant), Sanksi pajak, Pemahaman pajak

b. Dependent Variable: Kepatuhan

Sumber: data primer diolah, 2020

Nilai koefisen determinasi $\left(\mathrm{R}^{2}\right)$ digunakan untuk mengetahui keeratan hubungan antara variabel bebas dengan variabel terikat. Hasil analisis diperoleh nilai koefisien korelasi $\left(\mathrm{R}^{2}\right)$ menunjukkan adanya hubungan antara variabel $\mathrm{X}$ dengan variabel $\mathrm{Y}$ sebesar 0,683 yang dapat diartikan bahwa terdapat hubungan yang positif dan searah antara variabel $\mathrm{X}$ dengan variabel $\mathrm{Y}$ sebesar $68,3 \%$. Nilai koefisen determinasi digunakan untuk mengetahui pengaruh antara variabel bebas terhadap variabel terikat. Nilai $\mathrm{R}^{2}$ terletak antara 0 sampai dengan $1\left(0 \leq \mathrm{R}^{2} \leq 1\right)$. Hasil analisis diperoleh nilai koefisien determinasi $\left(\mathrm{R}^{2}\right)$ sebesar 0,464 Ini berarti, pengaruh variable $\mathrm{X}$ (pemahaman pajak, dan sanksi pajak) terhadap variable $\mathrm{Y}$ (kepatuhan wajib pajak) sebesar 46,6\% dan pengaruh variabel lainnya sebesar $53,4 \%$ yang tidak dimasukkan dalam model. Pengaruh ini tergolong cukup baik karena nilai yang diperoleh dibawah 50\%.

\section{Deskriptif Variabel Penelitian \\ Tabel Hasil Statistik Deskriptif \\ Descriptive Statistics}

\begin{tabular}{|l|r|r|r|r|r|}
\hline & $\mathrm{N}$ & Minimum & $\begin{array}{c}\text { Maximu } \\
\mathrm{m}\end{array}$ & Mean & $\begin{array}{c}\text { Std. } \\
\text { Deviation }\end{array}$ \\
\hline X1.1 & 100 & 4 & 5 & 4.53 & .502 \\
X1.2 & 100 & 2 & 5 & 4.40 & .603 \\
X1.3 & 100 & 3 & 5 & 4.34 & .555
\end{tabular}


Descriptive Statistics

\begin{tabular}{|l|r|r|r|r|r|}
\hline & $\mathrm{N}$ & Minimum & $\begin{array}{r}\text { Maximu } \\
\mathrm{m}\end{array}$ & Mean & $\begin{array}{c}\text { Std. } \\
\text { Deviation }\end{array}$ \\
\hline X1.4 & 100 & 2 & 5 & 4.32 & .634 \\
X2.1 & 100 & 3 & 5 & 4.40 & .752 \\
X2.2 & 100 & 2 & 5 & 3.84 & .884 \\
X2.3 & 100 & 1 & 5 & 3.62 & 1.099 \\
X2.4 & 100 & 3 & 5 & 4.64 & .689 \\
Y.1 & 100 & 2 & 5 & 4.08 & .872 \\
Y.2 & 100 & 2 & 5 & 4.20 & .829 \\
Y.3 & 100 & 2 & 5 & 4.26 & .848 \\
Y.4 & 100 & 3 & 5 & 4.76 & .553 \\
Valid N & 100 & & & & \\
(listwise) & & & & & \\
\hline
\end{tabular}

Berdasarkan tabel diatas diketahui sampel yang diamati dalam penelitian ini adalah sebanyak 100 sampel. Hasil pengujian statistik deskriptif, dapat didsimpulkan bahwa nilai rata-rata pada indikator variabel pemahaman pajak (X1) terdapat pada nilai mean 4.53 dimana nlai indikator variabel tersebut merupakan nilai tertinggi yang dapat diartikan sebagai pernyataan yg sangat baik dibandingkan pernyataan lainnya dari indikator variabel pemahaman pajak. Selanjutnya untuk indikator variabel sanksi pajak (X2) nilai tertinggi yang dinilai sangat baik terdapat pada nilai 4.64 yang menyatakan sanksi pidana yang dikenakan bagi pelanggar aturan pajak cukup berat. Dan yang terakhir variabel dependen (Y) Kepatuhan Pajak dapat dilihat nilai mean tertinggi terdapat pada 4.76 dimana nilai tersebut merupakan penryataan Wajib Pajak bersikap kooperatif (tidak menyusahkan) petugas pajak dalam pelaksanaan proses administrasi perpajakan.

\section{Hasil Uji F (Simultan)}

Pengujian yang dilakukan pada tahap ini adalah uji regresi dengan menggunakan uji statistik F. Hal ini dilakukan untuk membuktikan ada atau tidaknya pengaruh variabel X (independen) terhadap variabel Y (dependen). Dan hasilnya adalah sebagai berikut:

\begin{tabular}{|c|c|c|c|c|c|c|}
\hline \multicolumn{7}{|c|}{$\begin{array}{l}\text { Hasil Uji F } \\
\text { ANOVA }^{\mathbf{b}}\end{array}$} \\
\hline \multicolumn{2}{|c|}{ Model } & $\begin{array}{l}\text { Sum of } \\
\text { Squares }\end{array}$ & Df & $\begin{array}{l}\text { Mean } \\
\text { Square }\end{array}$ & $F$ & Sig. \\
\hline$\overline{1}$ & $\begin{array}{l}\text { Regressio } \\
n\end{array}$ & 283.869 & 2 & 141.934 & 42.345 & $.000^{\circ}$ \\
\hline & Residual & 325.131 & 97 & 3.352 & & \\
\hline & Total & 609.000 & 99 & & & \\
\hline
\end{tabular}

a. Predictors: (Constant), Sanksi

pajak,Pemahaman pajak 
ANOVA $^{\mathrm{b}}$

\begin{tabular}{|l|r|r|r|r|r|}
\hline \multicolumn{1}{|l|}{ Model } & \multicolumn{1}{c|}{$\begin{array}{c}\text { Sum of } \\
\text { Squares }\end{array}$} & Df & \multicolumn{1}{c|}{$\begin{array}{c}\text { Mean } \\
\text { Square }\end{array}$} & \multicolumn{1}{c|}{$\mathrm{F}$} & \multicolumn{1}{c|}{ Sig. } \\
\hline $1 \quad$ Regressio & 283.869 & 2 & 141.934 & 42.345 & $.000^{\mathrm{a}}$ \\
$\mathrm{n}$ & 325.131 & 97 & 3.352 & & \\
Residual & 609.000 & 99 & & & \\
\hline Total & & & \\
\hline
\end{tabular}

b. Dependent Variable:

kepatuhan wajib pajak

Berdasarkan hasil uji Anova atau $\mathrm{F}$ test terlihat bahwa nilai $\mathrm{F}$ sebesar 42.345 dengan nilai signifikansi sebesar 0,000 , karena probabilitas atau nilai sig menunjukkan 0,000 lebih kecil dari 0,05 maka model regresi dapat digunakan untuk memprediksi Pemahaman pajak dan Sanksi pajak secara bersama-sama atau secara simultan berpengaruh terhadap Kepatuhan wajib pajak pada kantor pajak di kabupaten Takalar

\section{Hasil Uji t (Parsial)}

Untuk menunjukkan seberapa jauh pengaruh satu variabel penjelas atau bebas secara individual dalam menerangkan variasi variabel terikat. Berikut ini akan dijelaskan pengujian masing-masing variabel secara parsial.

Uji t digunakan untuk membuktikan hipotesis dalam hal ini pengaruh variabel pemahaman pajak dan sanksi pajak terhadap kepatuhan wajib pajak pada kantor pajak di kabupaten Takalar, dengan taraf nyata sebesar 5\% atau 0,05, dimana derajat kebebasan (degree of freedom) yaitu $: \mathrm{df}=(\mathrm{n}-\mathrm{k})=100-3=97$, sehingga hasil $\boldsymbol{t}$-tabel yang diperoleh adalah 1,984 .

Hasil Uji Statistik t

Coefficients $^{\mathrm{a}}$

\begin{tabular}{|c|c|c|c|c|c|c|}
\hline \multirow{2}{*}{\multicolumn{2}{|c|}{ Model }} & \multicolumn{2}{|c|}{$\begin{array}{c}\text { Unstandardized } \\
\text { Coefficients }\end{array}$} & \multirow{2}{*}{$\begin{array}{c}\begin{array}{c}\text { Standardize } \\
d \\
\text { Coefficients }\end{array} \\
\text { Beta }\end{array}$} & \multirow[b]{2}{*}{$t$} & \multirow[b]{2}{*}{ Sig. } \\
\hline & & $B$ & Std. Error & & & \\
\hline \multirow[t]{3}{*}{1} & (Constant) & 4.862 & 2.438 & & 1.994 & .049 \\
\hline & $\begin{array}{l}\text { Pemahaman } \\
\text { pajak }\end{array}$ & .054 & .118 & .034 & .460 & .647 \\
\hline & Sanksi pajak & .696 & .076 & .682 & 9.194 & .000 \\
\hline
\end{tabular}

a. Dependent Variable: Kepatuhan wajib pajak

Sumber: Data Primer yang diolah

a. Pengujian thitung pada Variabel Tingkat Pemahaman Pajak

Hasil pengujian signifikansi menunjukkan bahwa variabel pemahaman pajak $\left(\mathrm{X}_{1}\right)$ terhadap kepatuhan wajib pajak $(\mathrm{Y})$ adalah sebesar $0.647>0.05$ dan nilai $\mathrm{t}$ hitung $0.460<\mathrm{t}$ tabel 1.984. Nilai tersebut dapat membuktikan Ho diterima dan Ha ditolak berarti tidak ada pengaruh yang signifikan anatara variabel tingkat pemahaman pajak terhadap kepatuhan wajib pajak. Hasil penelitian ini sesuai 
dengan penelitian yang dilakukan oleh Hardaningsih dan Yulianawati (2011) menunjukkan bahwa pengetahuan dan pemahaman tentang perpajakan tidak berpengaruh terhadap kepatuhan wajib pajak.

b. Pengujian t hitung pada Variabel Sanksi Pajak

Hasil pengujian signifikansi menunjukkan banwa variabel sanksi pajak $\left(\mathrm{X}_{2}\right)$ terhadap kepatuhan wajib pajak (Y) adalah sebesar $0.000<0.05$ dan nilai $t$ hitung $9.194>t$ tabel 1.984. Nilai tersebut dapat membuktikan Ho ditolak yang berarti bahwa ada pengaruh variabel sanksi perpajakan secara signifikan terhadap Kepatuhan wajib, dengan demikian hipotesis kedua terbukti. Hasil penelitian ini sesuai dengan penelitian Laura Yohana, (2016) tentang menunjukkan bahwa secara parsial sanksi perpajakan berpengaruh signifikan terhadap kepatuhan wajib pajak.

Dari hasil analisis regresi pada tabel diatas diperoleh persamaan regresi sebagai berikut:

$$
\begin{aligned}
& \mathbf{Y}=\boldsymbol{\beta}_{\mathbf{0}}+\boldsymbol{\beta}_{\mathbf{1}} \mathbf{X}_{\mathbf{1}}+\boldsymbol{\beta}_{\mathbf{2}} \mathbf{X}_{\mathbf{2}}+\mathbf{e} \\
& \mathrm{Y}=4,862+0,054 \mathrm{X} 1+0.696 \mathrm{X} 2+\mathrm{e}
\end{aligned}
$$

Persamaan regresi tersebut dapat dijelaskan sebagai berikut :

1. Nilai constanta (a) diperoleh sebesar 4.862 yang berarti bahwa kepatuhan wajib pajak sebesar 4.862 poin tanpa adanya pengaruh variabel independent (X1 dan X2).

2. Variabel Independent Pemahaman pajak (X1) berpengaruh positif terhadap kepatuhan wajib pajak (Y) dengan nilai koefisien sebesar 0, 054 yang berarti bahwa jika terjadi kenaikan tingkat kepatuhan wajib paka sebesar $1 \%$ maka pemahaman pajak juga akan mengalami kenaikan sebesar 0, 054 dengan asumsi bahwa variabel lain (X2) tetap.

3. Variabel Independent Sanksi Pajak (X2) berpengaruh positif terhadap kepatuhan wajib pajak (Y) dengan nilai koefisien sebesar 0,696 yang berarti bahwa jika terjadi kenaikan tingkat kepatuhan wajib pajak sebesar $1 \%$ maka kepatuhan wajib pajak juga akan mengalami kenaikan sebesar 0,696 dengan asumsi bahwa variabel lain (X1) tetap.

\section{PEMBAHASAN}

\section{Pengaruh Pemahaman Pajak terhadap Kepatuhan Wajib Pajak pada Kantor Pajak di Kabupaten Takalar}

Sesuai dengan hipotesis yang telah dijelaskan sebelumnya, peneliti menguji apakah tingkat pemahaman pajak memiliki pengaruh positif terhadap kepatuhan wajib pajak. Hasil analisis data menunjukkan hipotesis penelitian yang menyatakan bahwa pemahaman pajak tidak berpengaruh secara signifikan terhadap kepatuhan wajib pajak pada kantor pajak Kabupaten Takalar. Hal ini dibuktikan dengan nilai t-hitung untuk variabel $\mathrm{X}_{1}$ sebesar 0,460 dengan nilai probabilitas signifikan 0,647 $<0,05$ maka dapat disimpulkan Ho diterima Ha ditolak artinya bahwa pemahaman pajak tidak berpengaruh terhadap kepatuhan wajib pajak pada kantor Pajak Kabupaten Takalar.

Hal ini sesuai dengan yang dikemukakan oleh Radiya Faramita (2018) menyatakan bahwa pemahaman wajib pajak tidak berpengaruh signifikan terhadap kepatuhan wajib pajak. Selain itu penelitian yang dilakukan oleh Saragih F (2013) menyatakan bahwa pemahaman peraturan perpajakan (X2) terhadap kepatuhan wajib pajak orang pribadi (Y) memiliki nilai thitung 1,352 < 1,984 $\mathrm{H}_{0}$ diterima Ha ditolak 
mempunyai angka signifikan 0,179 >0,05. Berarti $\mathrm{H}_{0}$ ditolak $\mathrm{Ha}$ diterima hal ini menunjukkan bahwa tidak ada pengaruh yang signifikan antara pemahaman peraturan perpajakan terhadap kepatuhan wajib pajak orang pribadi pada KPP Pratama Medan Kota.

\section{Pengaruh Sanksi Pajak terhadap Kepatuhan Wajib Pajak pada Kantor Pajak di Kabupaten Takalar}

Berdasarkan hipotesis yang teelah dikjelaskan sebelumnya, peneliti menguji apakah sanksi pajak memiliki pengaruh positif terhadap kepatuhan wajib pajak. Hasil analisis data mendukung hipotesis penelitian yang meyatakan bahwa sanksi pajak memiliki pengaruh positif terhadap kepatuhan wajib pajak pada kantor pajak Kabupaten Takalar. Dimana sanksi pajak (X2) mempunyai hubungan positif atau searah, hal ini berarti bila sanksi pajak ditingkatkan, maka kepatuan wajib pajak juga meningkat. Hal ini dibuktikan dengan variabel $\mathrm{X}_{2}$ sebesar 9,194 nilai probabilitas signifikan $0,000<$ 0,05 maka dapat disimpulkan Ho ditolak dan Ha diterima, artinya bahwa Sanksi Pajak secara parsial berpengaruh terhadap kepatuhan wajib pajak pada kantor Pajak Kabupaten Takalar.

Penelitian ini sejalan dengan yang dilakukan oleh Putut Priambodo (2017) yang meyatakan Sanksi Perpajakan berpengaruh positif dan signifikan terhadap Kepatuhan Wajib Pajak yaitu sebesar 33,4\%, melihat besarnya pengaruh Sanksi Perpajakan terhadap Kepatuhan Wajib Pajak di KPP Pratama Purworejo seharusnya wajib pajak harus lebih mengetahui Sanksi Perpajakan agar Kepatuhan Wajib Pajak dapat ditingkatkan. Sanksi Perpajakan yang perlu diketahui dan ditaati oleh wajib pajak ada dua yaitu sanksi admnistrasi dan sanksi pidana, sanksi administrasi yaitu sanksi berupa pembayaran kerugian untuk negara, sedangkan sanksi pidana berupa pidana atau kurungan. Selanjutnya di dukung dengan penelitian yang dilakukan oleh Riano Roy Purnaditya (2015) yang menyatakan sanksi perpajakan memiliki pengaruh yang tinggi yang berlaku berpengaruh positif maupun signifikan terhadap kepatuhan wajib pajak.

\section{Pengaruh Pemahaman Pajak dan Sanksi Pajak terhadap Kepatuhan Wajib Pajak pada Kantor Pajak di Kabupaten Takalar}

Berdasarkan hasil hipotesis menyebutkan bahwa sanksi pajak berpengaruh dominan terhadap kepatuhan wajib pajak pada kantor Pajak di Kabupaten Takalar. Hasil analisis uji coefficient standardized beta diketahui diketahui nilai koefisien beta terstandarisasi (B) variabel Sanksi Pajak (B1) sebesar 0.682 lebih besar dari koefisien beta terstandarisasi variabel Pemahaman Pajak (B2) sebesar 0. .034. dengan demikian dapat dikatakan bahwa variabel Sanksi Pajak mempunyai pengaruh dominan terhadap Kepatuhan wajib pajak. Sehingga pengujian hipotesis Sanksi Pajak mempunyai pengaruh yang dominan terhadap kepatuhan wajib pajak pada kantor Pajak di Kabupaten Takalar dapat diterima.

Hal ini sejalan dengan penelitian yang dilakukan oleh Josephine Nidya Prajogo (2013) yang menyatakan sanksi perpajakan memiliki pengaruh yang tinggi dan dominan terhadap kepatuhan wajib pajak UMKM di wilayah Sidoarjo. Faktor kualitas pelayanan petugas pajak memiliki nilai beta yang paling rendah dibandingkan dengan nilai beta dari faktor-faktor lainnya, yaitu sebesar 0,210 . 


\section{SIMPULAN DAN SARAN}

Berdasarkan hasil penelitian dan analisis data yang telah diuraikan pada bab sebelumnya, dapat ditarik suatu kesimpulan sebagai berikut:

1. Hasil analisis data mendukung hipotesis penelitian yang menyatakan bahwa pemahaman pajak tidak memiliki berpengaruh signifikan terhadap kepatuhan wajib pajak pada kantor pajak Kabupaten Takalar.

2. Hasil analisis data mendukung hipotesis penelitian yang meyatakan bahwa sanksi pajak memiliki pengaruh positif terhadap kepatuhan wajib pajak pada kantor pajak Kabupaten Takalar. Dimana sanksi pajak (X2) mempunyai hubungan positif atau searah, hal ini berarti bila sanksi pajak ditingkatkan, maka kepatuan wajib pajak juga meningkat

3. Hasil analisis uji coefficient standardized beta diketahui diketahui nilai koefisien beta terstandarisasi (ß) variabel Sanksi Pajak lebih besar dari koefisien beta terstandarisasi variabel Pemahaman Pajak. dengan demikian dapat dikatakan bahwa variabel Sanksi Pajak mempunyai pengaruh dominan terhadap Kepatuhan wajib pajak. Sehingga pengujian hipotesis Sanksi Pajak mempunyai pengaruh yang dominan terhadap kepatuhan wajib pajak pada kantor Pajak di Kabupaten Takalar dapat diterima.

\section{SARAN}

Saran - saran yang ingin penulis sampaikan kepada pihak kantor pajak kabupaten Takalar adalah sebagai berikut :

1. Wajib pajak pada Kantor Pajak di Kabupaten Takalar diharapkan dapat lebih memahami tentang peraturan perpajakan dan juga dapat mengambil keputusan yang tepat dalam menghadapi risiko yang terjadi pada wajib pajak sendiri.

2. Penelitian selanjutnya diharapkan memiliki instrumen yang dapat mengukur tingkat kepatuhan wajib pajak dengan akurat serta memiliki indikator yang jelas dan kuar sebagai dasar instrumen pada kuesioner .

\section{DAFTAR PUSTAKA}

Adiasa Nirawan. 2013. Pengaruh Pemahaman Peraturan Pajak Terhadap Kepatuhan Wajib Pajak Dengan Preferensi Risiko Sebagai Variabel Moderating. Skripsi. Universitas Negeri Semarang

Arum, Harjanti Puspa. (2012). Pengaruh Kesadaran Wajib Pajak, Pelayanan Fiskus, dan Sanksi Pajak Terhadap Kepatuhan Wajib Pajak Orang Pribadi yang Melakukan Kegiatan Usaha dan Pekerjaan Bebas (Studi di Wilayah KPP Pratama Cialacap). Skripsi. Universitas Diponegoro. Semarang.

Info pajak.ID. 2017. Sanksi Bagi Yang Tidak Membayar Pajak dengan Benar. http://www.infopajak.id/sanksi-bagi-yang-tidak-membayar-pajak-denganbenar/.

Kadarukmi Retno. 2011. Peran Pajak Dalam Peningkatan Dunia Pendidikan. Jurnal Administrasi Bisnis, Vol.7, No.2: hal. 171-178, (ISSN:0216-1249). 
Kusuma. (2016). Pengaruh Kualitas Pelayanan Pajak, Pemahaman Peraturan Perpajakan Serta Sanksi Perpajakan Terhadap Kepatuhan Wajib Pajak Orang Pribadi Dalam Membayar Pajak Tahun 2014 (Studi Kasus pada Wajib Pajak yang Terdaftar di Kantor Pelayanan Penyuluhan dan Konsultasi Perpajakan Wonosobo).

Parera Andrea Meylita. 2017. Pengaruh Kesadaran Wajib Pajak, Sanksi Perpajakan, Pengetahuan Perpajakan, Dan Pelayanan Fiskus Terhadap Kepatuhan Wajib Pajak Bumi Dan Bangunan. Jurnal Akuntansi Vol. 5 No. 1, p-ISSN: 2088-768X | eISSN: 2540-9646 | DOI 10.24964/ja.v5i1.255

Purnaditya, Riano Roy. 2015. Pengaruh Pemahaman Pajak, Kualitas Pelayanan Dan Sanksi Pajak Terhadap Kepatuhan Pajak (Studi Empiris Pada WP OP yang Melakukan Kegiatan Usaha di KPP Pratama Semarang Candisari). Skripsi diterbitkan. Semarang. Program Sarjana Fakultas Ekonomika dan Bisnis Universitas Diponegoro.

Putut Priambodo. 2017. Pengaruh Pemahaman Peraturan Pajak, Sanksi Perpajakan, Dan Kesadaran Wajib Pajak, Terhadap Kepatuhan Wajib Pajak Orang Pribadi Di Kantor Pelayanan Pajak Pratama Kabupaten Purworejo Pada Tahun 2017. Skripsi. Fakultas Ekonomi Universitas Negeri Yogyakarta

Josephine Nidya Prajogo, Retnaningtyas Widuri 2013. Pengaruh Tingkat Pemahaman Peraturan Pajak Wajib Pajak, Kualitas Pelayanan Petugas Pajak, Dan Persepsi Atas Sanksi Perpajakan Terhadap Kepatuhan Wajib Pajak Umkm Di Wilayah Sidoarjo. Tax \& Accounting Review, Vol. 3, No.2, 2013

Undang-undang Dasar 1945 Pasal 31 ayat 4 Tentang Dana Pendidikan 